\title{
Puffy Frontal Edema: \\ A Serious Life-Threatening Finding of Pott's Puffy Tumor: Case Report
}

\author{
Frontal Kaba Şişlikli Ödem: \\ Hayati Tehlike Arz Eden Bulgularıyla \\ Pott'un Şişkin Tümörü
}

\begin{abstract}
Aslınur ÖZKAYA PARLAKAY, MD, Msc, ${ }^{\text {a }}$ ABSTRACT Osteomyelitis of the frontal bone, otherwise known as Pott's puffy tumour, is a rare Ateş KARA, MD, Prof., ${ }^{a}$ Ali Bülent CENGiZ, MD, Prof., ${ }^{a}$ Mehmet CEYHAN, MD, Prof. ${ }^{a}$

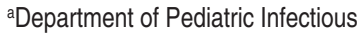
Diseases,

Hacettepe University Faculty of Medicine, Ankara complication of frontal sinusitis or direct injury to the frontal bone in adolescent age group. Pott's Puffy tumor can be complicated with cortical vein thrombosis, epidural abscess, subdural empyema, and brain abscess. Venous drainage of the frontal sinus flowing through diplopic veins, which have communication with the dural venous plexus is the cause of venous thrombosis. Through this venous system septic thrombi can potentially evolve and propagate from foci within the frontal sinus. We aimed to emphasize in this case report that Pott's puffy tumour should be considered in the differential diagnosis in a patient with swelling on the forehead, due to its high mortality rate of about $17 \%$.
\end{abstract}

Geliş Tarihi/Received: 18.05 .2010 Kabul Tarihi/Accepted: 05.06.2011

Yazışma Adresi/Correspondence: Aslınur ÖZKAYA PARLAKAY, MD, Msc Hacettepe University Faculty of Medicine, Department of Pediatric Infectious Diseases, Ankara TÜRKIYE/TURKEY aslinur@hacettepe.edu.tr

Key Words: Frontal sinusitis; osteomyelitis; Pott's puffy tumor

ÖZET Pott'un şişkin tümörü olarak da bilinen frontal kemiğin osteomiyeliti, adolesan çağdaki frontal sinüzitin veya frontal kemiğin doğrudan hasarının nadir bir komplikasyonudur. Pott'un şişkin tümörü, kortikal ven trombozu, epidural apse, subdural ampiyem ve beyin apsesi ile komplike olabilmektedir. Frontal sinüsün dural venöz pleksuslarla bağlantılı olan diploik venlere olan venöz drenaj1, venöz trombozun sebebidir. Bu venöz sistem boyunca ilerleyen odaklardan, frontal sinüs içinde yer alan septik trombüsler gelişebilmektedir. Bu olgu sunumunda, kafa ön bölgesinde şişlik olan bir hastada, mortalitesinin takriben \%17 olması nedeniyle, Pott'un şişkin tümörünün ayırıcı tanıda değerlendirilmesinin yararlı olabileceğini vurgulamayı amaçladık.

Anahtar Kelimeler: Frontal sinüzit; osteomiyelit; Pott’un şişkin tümörü

Turkiye Klinikleri J Med Sci 2012;32(3):850-3

doi: $10.5336 /$ medsci.2010-18408

Copyright $\odot 2012$ by Türkiye Klinikleri

P ott's puffy tumor was first described in 1760 by Percivall Pott (17141788), a surgeon at St. Bartholomew's Hospital in London, as “... if the symptoms of pressure such as stupidity, loss of sense, voluntary motion, etc. appear some few days after the head has suffered injury from external mischief, they do most probably imply an effusion of a fluid somewhere; in the substance of the brain, in its ventricles, between its membranes, or on the surface of the dura mater; but the inflammation of the dura mater, and the formation of matter between it and the skull, in consequence of contusion, is generally indicated and preceded by one [sign] which I have hardly ever known to fail; I mean a puffy, circumscribed, indolent tumor of the scalp, and a spontaneous separation of the pericranium, 
from the skull under such a tumor in the observation of the nature course of head trauma." ${ }^{1}$ Currently, it is defined as a forehead-localized swelling with overlying subperiosteal abscess and osteomyelitis of the frontal bone. ${ }^{2-5}$ In this case report we presented a 13-year old male patient with Pott's puffy tumour to emphasize the importance of early diagnosis and early initiation of therapy in the development of morbidity and mortality.

\section{CASE REPORT}

A 13-year old male patient was referred to our clinic with a one-week history of headache, fever and painful swelling on the forehead with an antibiotic and an antipyretic prescribed in a cottage hospital with the diagnosis of sinusitis. There was no trauma prior to this swelling. On physical examination, fever was $38^{\circ} \mathrm{C}$, there was a fluctuant, tender swelling $(2 \times 2 \mathrm{~cm})$ on the right part of the forehead and purulent postnasal discharge (Figure 1). There was no focal neurological deficit. Laboratory findings included white cell count 14.9

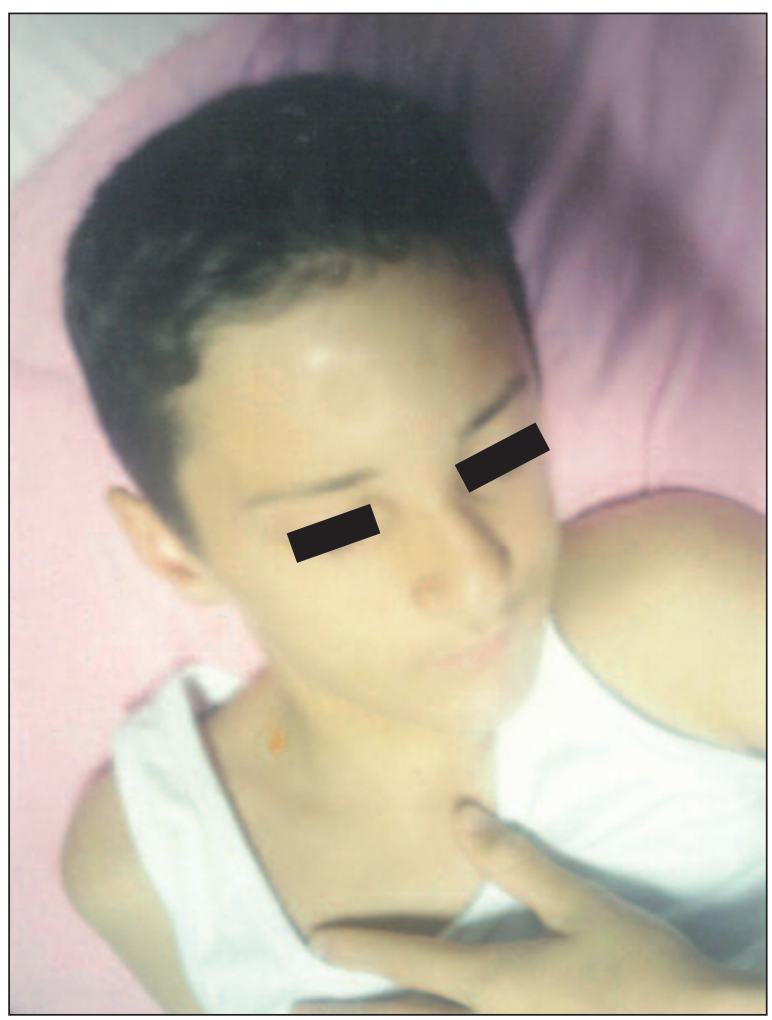

FIGURE 1: Appearance of Pott's puffy tumour on the right side of the forehead (See for colored form http://tipbilimleri.turkiyeklinikleri.com/) $\mathrm{x} 10^{9} / \mathrm{L}$, erythrocyte sedimentation rate 74 $\mathrm{mm}$ /hour and C-reactive protein $14.8 \mathrm{mg} / \mathrm{dl}(0-0.8$ $\mathrm{mg} / \mathrm{dl})$. Cranial computed tomography scan showed inflammatory changes in the frontal sinuses and soft tissue swelling on the right side of the frontal bone. Intravenous cefotaxime and vancomycine was administered for 14 days. As frontal abcess recovered with antibiotic therapy, no surgical intervention was implemented. No microorganism was recovered from the blood culture. He was discharged after 6 weeks of antibiotic therapy and he remained well during one and half years of follow-up.

\section{DISCUSSION}

Pott's puffy tumor is a frontal osteomyelitis accompanied by a subperiosteal abscess of the frontal bone. This "puffy" lesion arises when infection breaks through the outer edge of the frontal bone forming an abscess between the bone and the periosteum. It remains "circumscribed" because of tight adherence between the periosteum and the bone.

Pott's puffy tumor is often associated with antecedent sinusitis and less commonly with trauma. ${ }^{6}$ Pott's puffy tumor and its complications are a result of the unique configuration of the frontal sinuses and their vascular structures. The diploic veins drain into the frontal sinuses. These thinwalled, valveless vessels facilitate the hematogenous spread of the sinus infection to the bone and the brain..$^{7,8}$ The usual route for infection spread is from the frontal sinus to the frontal bone. The infection may further erode through the bony cortex, leading to the subperiosteal collection of pus described by Pott, or erode inward causing meningitis, epidural or subdural empyema, frontal lobe abscess, or cavernous sinus thrombosis. If the inferior wall of the frontal sinus is involved, infection may spread toward the orbit-leading to intraorbital abscess or orbital cellulitis. Pott's puffy tumor also can occur due to trauma (from insect bites to wrestling injuries) to the forehead of any patient with frontal sinusitis. ${ }^{9,10}$ Rarer risk factors for Pott's puffy tumor include osteocartilaginous necrosis secondary to chronic intranasal cocaine abuse, den- 
tal sepsis, or delayed complications of neurosurgery. ${ }^{11,12}$ In our case no prior trauma was present, frontal sinusitis might have led to Pott's puffy tumor.

Laboratory investigations are not usually helpful with an equivocal white cell count and normal erythrocyte sedimentation rate, which is presented in over $50 \%$ of the cases. ${ }^{13}$ The most common microorganisms in osteomyelitis of the skull are Streptococcus milleri or Staphylococcus aureus. ${ }^{14}$ Culture is required to identify the organism and appropriate antibiotic therapy should be started even if culture does not yield any microorganism. ${ }^{15} \mathrm{Al}$ though culture did not yield any microorganism in our case, antibiotic therapy is initiated immediately.

Tsai and his colleagues examined 6 Pott's puffy tumour patients and found the male-to-female ratio 5:1. The mean age at the time of diagnosis was 13.3 years. The risk factors were acute sinusitis in two (33\%) cases, chronic sinusitis in two (33\%), recent head trauma in two (33\%), and acupuncture therapy on skull in one (17\%). The most common presenting symptoms were fever, headache, forehead tenderness, vomiting and fatigue/malaise (100\%) in those patients. They diagnosed Pott's puffy tumor on average the seventh day after effervesence, and half of them had intracranial involvement at diagnosis. Intracranial involvement was in the form of intracranial infection, most of which were subdural empyema. The frontal sinus was involved in all cases (100\%). The frontal lobe was the most common area of involvement in intracranial infections (100\%); two thirds of those were polymicrobial from two or more sites. The average time of the initial operation was 5.8 days after the diagnosis. Half of the patients were reoperated. The mortality rate was $17 \%$ in that study. ${ }^{16}$

The incidence has decreased significantly in the post-antibiotic era but it may rise due to suboptimal treatment of frontal sinusitis. Although articles about Pott's puffy tumor are rare, many clinicians speculate that it is more common than cited in the literature. ${ }^{5}$ Pott's puffy tumor is more common in adolescents and young adults because adolescence corresponds with a peak in the vascularity of the diploic system and growth of the frontal sinus. ${ }^{17,18}$ Despite antimicrobial therapy, the mortality rate is $5-17 \% .{ }^{8,16}$ Symptoms including headache and little or no fever are often indolent. Increasing symptoms suggest complications.

Early diagnosis is critical to prevent complications. ${ }^{19}$ Imaging with computed axial tomography scan or magnetic resonance defines the extent of the infection..$^{20}$ In our case cranial computed tomography scan showed inflammatory changes in the frontal sinuses and soft tissue swelling on the right side of the frontal bone. A combined approach is suggested with 6 weeks of antimicrobials and surgery. Our patient received treatment for 6 weeks and he had no symptom during the 1.5 years of follow-up. Antimicrobial therapy should be tailored to the organisms isolated from surgical specimens. ${ }^{19}$ Surgery is indicated for abscess drainage, bony debridement, and trephination of the frontal sinus. ${ }^{21}$

We aimed to emphasize in this case report that Pott's puffy tumour should be considered when a patient presents with a swelling on the forehead since mortality rate might be as high as $17 \%{ }^{16}$

\section{REFERENCES}

1. Pott P. Observations on the Nature of Consequences of Wounds and Contusions of the Head, Fractures of the Skull, Concussions of the Brain. $1^{\text {st }}$ ed. London, UK: Hitch \& Lowes; 1760. p.38-58.

2. Bambakidis NC, Cohen AR. Intracranial complications of frontal sinusitis in children: Pott's puffy tumor revisited. Pediatr Neurosurg 2001;35(2):82-9.

3. Forgie SE, Marrie TJ. Pott's puffy tumor. Am J Med 2008;121(12):1041-2.

4. Kombogiorgas D, Solanki GA. The Pott puffy tumor revisited: neurosurgical implications of this unforgotten entity. Case report and review of the literature. J Neurosurg 2006;105(2 Suppl):143-9.

5. Tattersall R, Tattersall R. Pott's puffy tumour. Lancet 2002;359(9311):1060-3.

6. Bordley JE, Bischofberger W. Osteomyelitis of the frontal bone. Laryngoscope 1967;77(8): 1234-44. 
7. Clarke JR, Lim JK, Poole M. Pott's puffy tumor: a clinical variant. Aust NZ J Surg 1999; 69(10):759-62.

8. Lang EE, Curran AJ, Patil N, Walsh RM, Rawluk D, Walsh MA. Intracranial complications of acute frontal sinusitis. Clin Otolaryngol 2001; 26(6):452-7.

9. Raja V, Low C, Sastry A, Moriarty B. Pott's puffy tumor following an insect bite. J Postgrad Med 2007;53(2):114-6.

10. Tudor RB, Carson JP, Pulliam MW, Hill A. Pott's puffy tumor, frontal sinusitis, frontal bone osteomyelitis and epidural abscess secondary toa wrestling injury. Am J Sports Med 1981;9(6):390-1.

11. Noskin GA, Kalish SB. Pott's puffy tumor: a complication of intranasal cocaine abuse. Rev Infect Dis 1991;13(4):606-8.

12. Chandy B, Todd J, Stucker FJ, Nathan CO. Pott's puffy tumor and epidural absces arising from dental sepsis: a case report. Laryngoscope 2001;111(10):1732-4.

13. Koch SE, Wintroub B. Pott's puffy tumour. A clinical marker for osteomyelitis of the skull. Arch Dermatol 1985;121(4):548-9.

14. Marshall AH, Jones NS. Osteomyelitis of the frontal bone secondary to frontal sinusitis. $J$ Laryngol Otol 2000;114(12):944-6.

15. Procino ND. Pott's puffy tumour in a seven year old. Ear, Nose Throat J 1978;57(11):848.

16. Tsai BY, Lin KL, Lin TY, Chiu CH, Lee WJ,
Hsia SH, et al. Pott's puffy tumor in children. Childs Nerv Syst 2010;26(1):53-60.

17. Furstenberg AC. Osteomyelitis of the skull. Ann Otol 1931;40:996-1012.

18. Woodward FD. Osteomyelitis of skull. JAMA 1930;95(13):927-30.

19. McDermott C, O'Sullivan R, McMahon G. An unusual cause of headache: Pott's puffy tumor. Eur J Emerg Med 2007;14(3):170-3.

20. Babu RP, Todor R, Kasoff SS. Pott's puffy tumor: the forgotten entity. J Neurosurg 1996; 84(1):110-2.

21. El-Silimy O. Combined endonasal and percutaneous endoscopic approach to Pott's puffy tumor. Rhinology 1996;34(2): 119-22. 